\title{
Impact of Foreign Direct Investment on Small and Medium Scale Enterprises in Pakistan
}

\author{
${ }^{a}$ Muhammad Zahir Faridi, ${ }^{\mathrm{b}}$ Saddam Hussain, ${ }^{\mathrm{c}}$ Muhammad Imran, ${ }^{\mathrm{d}}$ Rashid Ahmad \\ ${ }^{a}$ Professor, School of Economics, Bahauddin Zakariya University, Multan, Pakistan \\ Email: zahirfaridi@bzu.edu.pk \\ ${ }^{\mathrm{b}}$ PHD Scholar, School of Economics, Bahauddin Zakariya University, Multan, Pakistan \\ Email: saddamHussainsial1@gmail.com \\ ${ }^{\mathrm{c}}$ PHD Scholar, School of Economics, Bahauddin Zakariya University, Multan, Pakistan \\ Email: hopeimran@gmail.com \\ ${ }^{\mathrm{d}}$ Assistant Professor, School of Economics, Bahauddin Zakariya University, Multan, Pakistan \\ Email: rashidahmad@bzu.edu.pk
}

\begin{tabular}{|c|c|}
\hline ARTICLE DETAILS & ABSTRACT \\
\hline History: & \multirow{9}{*}{$\begin{array}{l}\text { This study attempts to analyze the impact of foreign direct investment } \\
\text { on the small and medium scale enterprises in Pakistan by using the } \\
\text { annual time series data from period of } 1982 \text { to } 2019 \text {. ADF unit root test, } \\
\text { ARDL model and granger causality test are used to analyze the data. The } \\
\text { outcomes of long-run ARDL model exhibits that foreign direct } \\
\text { investment, gross savings, exports of goods and services positively } \\
\text { enhance the performance of small and medium scale enterprises in } \\
\text { Pakistan. In Granger causality analysis, it is found that there is a } \\
\text { unidirectional causality between SME growth rate and foreign direct } \\
\text { investment. The unidirectional causality is also observed between gross } \\
\text { savings and SME growth rate. It is therefore suggested that an } \\
\text { appropriate environment to the foreign investors may be provided to } \\
\text { bring foreign direct investment inflows in a country. Government of } \\
\text { Pakistan may improve the infrastructure in a country to increase FDI } \\
\text { inflows. }\end{array}$} \\
\hline Accepted 27 May 2021 & \\
\hline Available Online June 2021 & \\
\hline Keywords: & \\
\hline & \\
\hline Gross Savings, Exports & \\
\hline JEL Classification: & \\
\hline$F 21, L 26$ & \\
\hline DOI: 10. & \\
\hline
\end{tabular}

(C) 2021 The authors. Published by SPCRD Global Publishing. This is an open access article under the Creative Commons AttributionNonCommercial 4.0

Corresponding author's email address: rashidahmad@bzu.edu.pk

\section{Introduction}

In today's global world, foreign direct investment (FDI) play an imperative role in economic progress of any country. It may open up new markets and marketing channels for organizations, financing, access to modern technology, and skills. It provides capital, managerial skills, and technologies to the host country and leads to the boost in economic development. In simple words foreign direct investment can be defined as a company from one country making a physical investment in the building of a plant in another country. To put it another way, FDI is an investment that involves a long-term connection and reflects a long-term interest and control of a resident entity in one economy 
in a business that is located in another economy than the foreign direct investor's (Rajak, 2020).

Foreign direct investment recent countries provide with a variety of advantages that help them thrive economically. First, FDI sends financial resources to recipients or host nations, which may then be utilized to develop production facilities. Second, technology and managerial know-how, both of which are critical for economic growth, may be transmitted to the host nations. Third, FDI allows host nations to engage in different networks, such as foreign investor sales and procurement networks. Using international networks, host nations may increase not just exports but also import high-quality materials, boosting productivity in the host countries (Urata\& Kawai, 2000).

Aside from the advantages that may be achieved from receiving FDI from foreign businesses of all sizes, there are some extra advantages that host nations can receive from receiving FDI in small and medium-sized organizations. First, by receiving FDI, SMEs involved in metal and machinery production, parts and component suppliers, which are not adequately established in most developing countries but are crucial for fostering industrialization. FDI by SMEs would also help the host country's economic growth by improving income distribution, since they give jobs and income to local people with less experience and education by employing labor-intensive technology (Urata \& Kawai, 2000).

Given the importance of entrepreneurship in a country's economic progress and the lack of appropriate technology in developing nations, it is vital to pursue technology transfer. Small and medium enterprises in developing nations, in particular, rely on access to markets and knowledge to survive and expand. Access to knowledge enables SMEs to make effective investments and acquire advanced technology, ensuring their competitiveness and that of the country as a whole (Subair \& Salihu, 2011). This advancement in technology can be obtained through the spill-over effects of foreign direct investment. This is due to the fact that FDI is one of the most important source for transmitting modern scientific knowledge and technological innovations (Dutse, 2008).

Small and medium scale enterprises are important for increased utilization of domestic raw materials, employment creation, rural development, entrepreneurship development, mobilization of local savings, connections with larger industries, provision of employment opportunities, and provision of opportunities for training and development of managers (Taiwo et al. 2012).

Pakistan's economy, like economies of developing countries, is reliant on small and mediumscale enterprises. The SME sector contributes significantly to economic growth, technical innovation, economic renewal, souring to large organizations and social progress (Khalique et al. 2011). They may be developed for any type of company activity in both urban and rural areas. Income, employment, and poverty alleviation are all generated as a result of the formation and growth of these types of businesses. As a result, the creation of jobs by SMEs supports economic progress in rural regions (Oyelana \& Adu, 2015). The SME sector in developing countries is facing lot of problems like shortage of capital and financial opportunities, high interest bearing loans, poor infrastructure, and lack of modern technology (Manzoor et al. 2021).

In Pakistan, the SME sector accounts for approximately 40\% of GDP, and it have enormous potential to boost the country's economy (SMEDA, 2020). Small and Medium Enterprises Development Authority (SMEDA) has made numerous steps to encourage SMEs' growth through a comprehensive service of portfolio distributing across various SME sectors and clusters, allowing them to play their proper part in economic development in Pakistan. The organization's aim is to support SME growth through a variety of services, including business and infrastructure development via the establishment 
of common facility centers, development of human capital via training programs, and industry support for enhancement in productivity (Pakistan Economic Survey, 2020-21). Small and medium scale enterprises draw the attention and interest of academics policymakers although there is still need to examine the boosting factors of SMEs. This study particularly analyzes the role of foreign direct investment in addition to some other factors in affecting the output of SMEs in Pakistan. The result of the study is arranged as follow. The second section provides the review of some latest studies. The issues regarding data sources and methodology are described in the section $3^{\text {rd }}$. the fourth section is about results and discussion. The last section concludes the study and suggests the some policy recommendation.

\section{Literature Review}

Manzoor et al. (2021) explored the association between SMEs and economic growth in Pakistan by using data from 1990 to 2019. The SMEs output, human development index, and credit to the expansion of the sector were recognized as the encouraging factors of economic growth in the long-run whereas human development index, SME's output and exports were the encouraging factors in the short-run. Idehen \& Iguisi (2020) examined the explored of FDI on SMEs output in Nigeria by using data from 1991 to 2018. The findings indicated that the value of foreign private investment and foreign portfolio investment had an adverse association with SME development. FDI and the rate of exchange had adverse and substantial influence on SME development in Nigeria.

Sohail \& Mirza (2020) used data from 1996 to 2015 to observe the influence of FDI on economic growth of Pakistan. The findings showed that FDI and GDP had a significant relationship. Independent variables that influenced the country's economic growth including exports, domestic capital, the human capital index, and the amount of terrorist strikes. Dinh et al. (2019) looked at the influence of FDI on economic development in developing nations. The findings of this study demonstrated that FDI helped to promote economic growth in the long term. Other macroeconomic factors also had a part in explaining these countries' economic progress. Economic growth in the long-run was also influenced by money supply, human capital, total domestic investment and private sector domestic credit.

Mwika et al. (2018) studied the linkage between SMEs and globalization in Zambia. Globalization had a detrimental impact on these SMEs. In light of the findings, the general assumption that globalization had a substantial influence in developing nations. Oladimeji et al. (2017) investigated the association between globalization and SMEs performance in Nigeria. The influence of globalization on performance of SMEs was investigated using a co-integration model. Interest rates, bank lending, and trade openness were shown to have partial effect on the production of SMEs. Hussain (2017) examined the impact of FDI on local firm's productivity in Pakistan. The findings showed that foreign direct investment, capital intensity, economies of scale, company size, and firm age all had a direct and substantial influence on productivity of labor in Pakistan.

Oyedele et al. (2016) explored the influence of globalization on the growth of small and medium companies in Nigeria. The findings showed that globalization has a favorable and considerable impact on job creation. The findings also showed that globalization had a positive and substantial association with poverty reduction. Abdullahi \& Sulaiman (2015) investigated the factors that influence the SMEs performance in Nigeria. An ARDL approach to co-integration was used on a sample from 1981 to 2010. The findings indicated that interest rates and net export had a detrimental influence on SMEs' success in both short and long run. Kunle et al. (2014) looked at the influence of FDI on economic growth of Nigeria by utilizing the data from 1999 to 2013. The OLS estimates indicated that economic growth was strongly connected to inflows of foreign direct investment. Chughtai (2014) diagnosed the influence of 
FDI on economic growth. The findings demonstrated that FDI directly influenced the economic growth. The findings also showed a long-run causation between FDI and Gross domestic Product.

Taiwo et al. (2012) explored the aspects that affect SMEs output in Nigeria. Findings indicated that shortage of financial assistance, corruption, poor management, lack of training; inadequate infrastructure, insufficient profitability, and low demand for products and services were the most frequent barriers to growth. Ray (2012) used the co-integration technique to assess the role of FDI in India's economic progress from 1990 to 2011. The empirical study based on the conventional Least Square Method showed that FDI and GDP were positively associated. The co-integration test indicated the presence of a long-run equilibrium connection between the two, which was also verified by the findings of the Johansen co-integration test. Finally, the Granger causality analysis showed the existence of unidirectional causation between economic development and foreign direct investment.

Subair \& Salihu (2011) looked at the influence of FDI on SME development in Nigeria, and the ordinary least square method was used to analyze data. The study's findings were more precise while also addressing SMEs in several sectors of the Nigerian economy in terms of FDI. It was obvious that FDI had a detrimental impact on the growth of SMEs. Louzi \& Abadi (2011) examined the role of FDI in enhancing economic growth in Jordan. The research was based on data spanning the years 1990 to 2009. To capture two-way connections between variables of interest, co-integration and error correction model were utilized. According to an econometric finding, FDI inflows had no substantial impact on economic growth. Domestic investment and trade liberalization have also been proven to have a favorable influence on GDP growth rates.

Gudaro et al. (2010) explored the effects FDI in Pakistan from 1981 to 2010. The outcomes revealed an optimistic and substantial link between FDI and GDP. They found a negative association between inflation and GDP. Urata \& Kawai (2000) investigated the determinants of FDI location by Japanese businesses. The study revealed that both supply and demand side characteristics in the host countries were key determinants. The availability of low-wage labor, strong infrastructure, and decent governance were all supply-side variables, whereas the presence of a large local market was a demandside factor. Industrial agglomeration, which includes both supply- and demand-side aspects, had a significant impact on Japanese company decision-making. Antwi et al. (2013) used time series data from 1980 to 2010 to analyze the association between FDI and economic growth in Ghana. These outcomes point out that FDI had an optimistic influence on Ghana's economic growth.

\section{Data and Methodology}

\subsection{Data Sources}

This study is based on secondary data sources and exercised Pakistan's annual time series data which covers a period from 1982 to 2019. The main sources of data are world development indicators and Pakistan economic survey. The dependent variable is used in a model is growth rate of SMEs output while the core independent variable is foreign direct investment. The control variables are GDP growth rate, gross savings and exports of goods and services. The ADF unit root test is employed for solving the stationary problem and ARDL model is used to analyze the data because of the mix order of integration.

\subsection{Model Specification}

To analyze the impact of foreign direct investment on the small and medium scale enterprises the following model is developed:

$$
S M E_{i}=\beta_{o}+\beta_{1} L N F D I_{i}+\beta_{2} G S_{i}+\beta_{3} G D P G R_{i}+\beta_{4} E X P_{i}+u_{i}
$$


Where;

SME: SME growth rate

LNFDI: natural log of foreign direct investment

GDPGR: GDP growth rate

EXP: Exports of goods and services

$\mathrm{u}_{\mathrm{i}}$ : error term

Table 1: Description of Variables

\begin{tabular}{|l|l|l|c|}
\hline Variables & Description of Variables & Measurement unit & Data Sources \\
\hline Dependent Variable & \multicolumn{2}{|l|}{} \\
\hline SME & SME growth rate & Rate & $\begin{array}{l}\text { Pakistan Economic } \\
\text { Survey }\end{array}$ \\
\hline Independent Variables & $\begin{array}{l}\text { Natural log of Foreign direct } \\
\text { investment }\end{array}$ & $\begin{array}{l}\text { Net inflows in million US } \\
\text { dollars }\end{array}$ & WDI \\
\hline FDI & Gross domestic product growth rate & Annual & WDI \\
\hline GDPGR & Gross Savings & As a percentage of GDP & WDI \\
\hline GS & Exports of goods and services & As a percentage of GDP & WDI \\
\hline EXP &
\end{tabular}

\section{Results and Discussion}

The descriptive statistics of data is presented in Table 2. The descriptive statistics of data provides different characteristics about the variables such as mean, median, minimum, maximum skewness, kurtosis and Jarque-Bera test. Table 2 shows that the mean growth rate of SMEs is 7.186, maximum growth rate is 8.701 , minimum growth rate is 3.501 , standard deviation, shows the deviation from mean, is 1.352, skewness value is -0.875 , kurtosis value is 2.887 and Jarque-Bera value is 4.866 on the average the value of FDI is 126 units with 142 units of variability. The values Skewness and Kurtosis are 1.67 and 5.30 respectively

Table 2: Descriptive Statistics

\begin{tabular}{|c|c|c|c|c|c|}
\hline & SME & FDI & GS & GDPGR & EXP \\
\hline Mean & 7.186 & 126 & 22.857 & 4.644 & 13.357 \\
\hline Median & 7.501 & 71.9 & 22.274 & 4.896 & 13.426 \\
\hline Maximum & 8.701 & 559 & 31.154 & 7.706 & 17.359 \\
\hline Minimum & 3.501 & 2.946 & 16.888 & 0.989 & 8.257 \\
\hline Std. Dev. & 1.352 & 142 & 3.286 & 1.893 & 2.433 \\
\hline Skewness & -0.875 & 1.67 & 0.567 & -0.266 & -0.214 \\
\hline Kurtosis & 2.887 & 5.30 & 2.760 & 2.230 & 2.255 \\
\hline Jarque-Bera & 4.866 & 26.0427 & 2.128 & 1.387 & 1.169 \\
\hline Probability & 0.088 & 0.000002 & 0.345 & 0.500 & 0.558 \\
\hline
\end{tabular}

Source: Author's Calculations 
Table 3 presents the correlation matrix. It shows the degree of association among the variables. It is observed that small and medium scale enterprises growth rate is positively correlated with foreign direct investment with value (0.579), exports (0.015) while negatively correlated with gross savings and GDP growth rate (0.015).

Table 3: Pairwise Correlation Matrix

\begin{tabular}{|c|c|c|c|c|c|}
\hline Variables & SME & FDI & GS & GDPGR & EXP \\
\hline SME & 1.000 & & & & \\
\hline FDI & 0.579 & 1.000 & & & \\
\hline GS & -0.201 & -0.675 & 1.000 & & \\
\hline GDPGR & -0.054 & -0.359 & 0.540 & 1.000 & -0.129 \\
\hline EXP & 0.015 & -0.102 & -0.094 & 1.000 \\
\hline
\end{tabular}

Source: Author's Calculations

Table 4 presents the findings of ADF unit root test. The variable SME $(t$-stat. $=-6.465, p$-value $=$ o.ooo), FDI ( $t$-stat. $=-5.491, p$-value $=0.0001)$, GS $(t$-stat $.=-6.635, p$-value $=0.000)$ and $\mathrm{EXP}(t-s t a t .=-$ $5.254, p$-value $=0.000)$ are stationary at $1^{\text {st }}$ difference while the variable GDPGR $(t$-stat. $=-3.327, p-$ value $=0.000$ ) is stationary at level.It advocates that ARDL method is an appropriate technique for longrun analysis.

Table 4: Unit Root Analysis

\begin{tabular}{|c|c|c|c|c|c|c|c|c|c|}
\hline \multirow{3}{*}{ Variables } & \multicolumn{4}{|c|}{ Level } & \multicolumn{4}{|c|}{$\mathbf{1}^{\text {st }}$ Difference } & \multirow{3}{*}{$\begin{array}{c}\text { Integration } \\
\text { Order }\end{array}$} \\
\hline & \multicolumn{2}{|c|}{ Intercept } & \multicolumn{2}{|c|}{$\begin{array}{c}\text { Intercept and } \\
\text { Trend }\end{array}$} & \multicolumn{2}{|c|}{ Intercept } & \multicolumn{2}{|c|}{$\begin{array}{c}\text { Intercept and } \\
\text { Trend }\end{array}$} & \\
\hline & t-stat. & $\begin{array}{c}\text { p- } \\
\text { value }\end{array}$ & t-stat. & p-value & t-stat. & $\begin{array}{c}\mathrm{p}- \\
\text { value }\end{array}$ & t-stat. & $\begin{array}{c}\text { p- } \\
\text { value }\end{array}$ & \\
\hline SME & -- & -- & -- & -- & -6.465 & 0.0000 & -- & -- & $\mathrm{I}(1)$ \\
\hline FDI & -- & -- & -- & -- & -5.491 & 0.0001 & -- & -- & $\mathrm{I}(1)$ \\
\hline GS & -- & -- & -- & -- & -6.635 & 0.000 & -- & -- & $\mathrm{I}(1)$ \\
\hline GDPGR & $-3 \cdot 327$ & 0.020 & -- & -- & -- & -- & -- & -- & $\mathrm{I}(\mathrm{o})$ \\
\hline EXP & -- & -- & -- & -- & -5.254 & 0.0001 & -- & -- & $\mathrm{I}(1)$ \\
\hline
\end{tabular}

Source: Author's Calculations

ARDL bound test analysis is helpful in examine either the long co-integration exists between the variables or not. Table 5 presents the ARDL bound test analysis and show that F-statistic value (8.0046) is greater than all critical lower and upper bound values so it recommends that there is a long run cointegration between variables. 
Table 5: ARDL Bound Test Analysis

\begin{tabular}{|c|c|c|}
\hline Test Statistic & Value & k \\
\hline F-statistic & 8.0046 & 4 \\
\hline \multicolumn{3}{|c|}{ Critical Value Bounds } \\
\hline Significance & Io Bound & I1 Bound \\
\hline $10 \%$ & 2.45 & 3.52 \\
\hline $5 \%$ & 2.86 & 4.01 \\
\hline $2.5 \%$ & 3.25 & 4.49 \\
\hline $1 \%$ & 3.74 & 5.06 \\
\hline
\end{tabular}

Source: Author's Calculations

Table 6 portrays the long-run estimates of impact of foreign direct investment on growth of small and medium scale enterprises. The dependent variable exercised in our study is growth rate of SMEs. The findings indicate that all the variables are positively and significantly related to the targeted variable. The core variable of our study is FDI inflows that exhibit positive and statistically significant relationship with small and medium scale enterprises. The value of the coefficient is 2.0913 that clearly shows if there is one percent increase in foreign direct investment it leads to the growth of SMEs almost 2.09. FDI provides important benefits to the firms of the developing countries by providing funds, technical skills, and technology which lead to the boost in overall economy (Baiashvili \& Gattini, 2020). The coefficient of the gross savings also has a positive sign. It exhibits the positive relationship with a SMEs. The coefficient value shows that as the gross savings increases by one unit it leads to growth of SMEs by 0.7264 units our findings support to the findings of Jayasekara \& Thilakarathna 2013. Gross domestic product growth rate also has a positive sign and directly linked with SMEs. As the GDP growth rate increases by one unit it leads to growth of SMEs by 2.5091 units. It is observed that exports also have positive sign that exhibits the positive relationship with SMEs. The coefficient value indicates that as the exports of goods and services increases by one unit it raises growth of SMEs by 0.4971 units.

Table 6: ARDL Long Run Estimates

\begin{tabular}{|c|c|c|c|c|}
\hline \multicolumn{5}{|c|}{ Dependent Variable: Growth Rate of SMEs } \\
\hline Variables & Coefficient & Std. Error & t-Statistic & Prob. \\
\hline FDI & 2.0913 & 0.4468 & 4.6806 & 0.0004 \\
\hline GS & 0.7264 & 0.2592 & 2.8014 & 0.0141 \\
\hline GDPGR & 2.5091 & 0.6387 & 3.9279 & 0.0015 \\
\hline EXP & 0.4971 & 0.2141 & 2.3210 & 0.0359 \\
\hline C & -68.3357 & 18.7526 & -3.6440 & 0.0027 \\
\hline
\end{tabular}

Source: Author's Calculations

Table 7 explains the short-run error correction model. The error correction term CointEq(-1) shows 47.13 percent speed of adjustment to the long-run equilibrium if any disturbances observed in a short run. The value of the error correction term is negative, less than one and statistically significant it confirms the co-integration relationship between variables. 
Table 7: Short-Run Error Correction Model

\begin{tabular}{|c|c|c|c|c|}
\hline Variable & Coefficient & Std. Error & t-Statistic & Prob. \\
\hline D(SME (-1)) & -0.3015 & 0.1632 & -1.8471 & 0.0860 \\
\hline D(SME (-2)) & -0.3192 & 0.1329 & -2.4006 & 0.0308 \\
\hline D(FDI) & -0.7475 & 0.4110 & -1.8186 & 0.0904 \\
\hline D(FDI(-1)) & 0.2750 & 0.3149 & 0.8732 & 0.3973 \\
\hline D(FDI(-2)) & -1.4046 & 0.3261 & -4.3069 & 0.0007 \\
\hline D(FDI(-3)) & -0.8554 & 0.3754 & -2.2785 & 0.0389 \\
\hline D(GS) & 0.2596 & 0.0538 & 4.8265 & 0.0003 \\
\hline D(GDPGR) & 0.2353 & 0.0881 & 2.6702 & 0.0183 \\
\hline D(GDPGR(-1)) & -0.3198 & 0.0862 & -3.7089 & 0.0023 \\
\hline D(GDPGR(-2)) & -0.2482 & 0.0717 & -3.4596 & 0.0038 \\
\hline D(GDPGR(-3)) & -0.1006 & 0.0744 & -1.3522 & 0.1977 \\
\hline D(EXP) & -0.0692 & 0.1013 & -0.6835 & 0.5054 \\
\hline D(EXP (-1)) & -0.0333 & 0.1425 & -0.2336 & 0.8186 \\
\hline D(EXP (-2)) & -0.2142 & 0.1510 & -1.4180 & 0.1780 \\
\hline CointEq(-1) & -0.4713 & 0.1266 & -3.7209 & 0.0023 \\
\hline
\end{tabular}

Source: Author's Calculations

To check the autocorrelation and heteroscedasticity in a model Breusch-Godfrey and Breusch-PaganGodfrey test is used. Table 8 presents the estimates of these tests. The outcomes of model tests show that there is no problem of autocorrelation and heteroscedasticity in a model.

Table 8: Normality Test

\begin{tabular}{|l|r|r|r|}
\hline \multicolumn{4}{|c|}{ Breusch-Godfrey Serial Correlation LM Test } \\
\hline F-statistic & 1.485 & Prob. F(2,12) & 0.2652 \\
\hline \multicolumn{4}{|c|}{ Heteroskedasticity Test: Breusch-Pagan-Godfrey } \\
\hline F-statistic & 0.449 & Prob. F(19,14) & 0.9472 \\
\hline
\end{tabular}

Source: Author's Calculations

To check the stability of a model, recursive residuals cumulative sum and cumulative sum of squares is used. Figure 1 shows that our ARDL model is dynamically stable over the long-run as the fitted lines (blue lines) are within the range of critical lines (red lines) at 5 percent significance level.

Figure 1: Stability Test
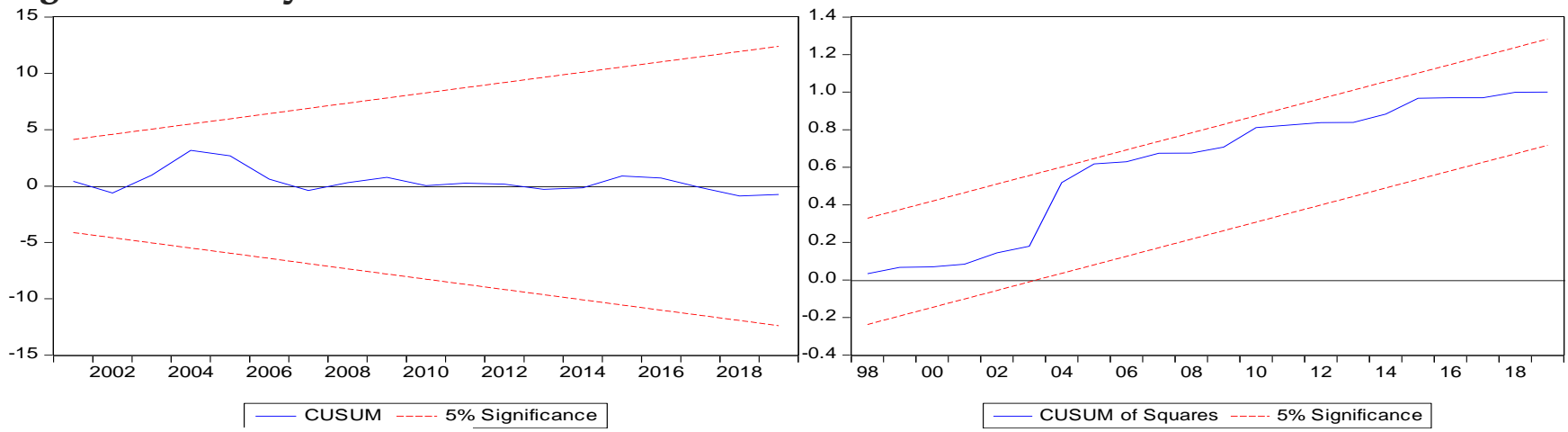

Source: Author's Calculations 
Table 9 presents the granger causality analysis. It can be noted from Table 9 that there is a unidirectional causality between SME growth rate and FDI. The unidirectional causality is also observed between gross savings and SME growth rate. No causality found between GDP growth rate and SME growth rate.

Table 9: Granger Causality Analysis

\begin{tabular}{|l|c|c|r|}
\hline \multicolumn{1}{|c|}{ Null Hypothesis: } & Obs & F-Statistic & Prob. \\
\hline FDI does not Granger Cause SME & 37 & 0.350 & 0.5576 \\
\hline SME does not Granger Cause FDI & & 7.519 & 0.0097 \\
\hline GS does not Granger Cause SME & 37 & 0.244 & 0.6239 \\
\hline SME does not Granger Cause GS & & 7.284 & 0.0108 \\
\hline GDPGR does not Granger Cause SME & 37 & 0.193 & 0.6627 \\
\hline SME does not Granger Cause GDPGR & 37 & 0.636 & 0.4306 \\
\hline EXP does not Granger Cause SME & & 2.208 & 0.1464 \\
\hline SME does not Granger Cause EXP & & 0.508 & 0.4809 \\
\hline
\end{tabular}

Source: Author's Calculations

\section{Conclusions and Recommendations}

The primary objective of this analysis is to analyze the impact of foreign direct investment on the small and medium scale enterprises in Pakistan by utilizing the annual time series data from 1982 to 2019. ADF unit root test, ARDL model and granger causality test is used to analyze the results. The correlation analysis found that SME growth rate is positively correlated with foreign direct investment, exports while negatively correlated with gross savings and GDP growth rate. ADF test found that the variable SME, FDI, GS and EXP are stationary at $1^{\text {st }}$ difference while the variable GDPGR is stationary at level it advocates that ARDL method is an appropriate technique for long-run analysis. The outcomes long-run ARDL model exhibited that foreign direct investment, gross savings, exports of goods and services and gross savings positively enhanced the performance of SMEs in Pakistan. Granger causality analysis found that there is a unidirectional causality between SME growth rate and foreign direct investment. The unidirectional causality is also observed between gross savings and SME growth rate.

Based on the outcomes of the study it is concluded that FDI inflows boosts the performance of small and medium scale enterprise in Pakistan. It suggests that local firms in Pakistan gaining advantages of FDI. Foreign direct investment brings investment, advance technology, skilled management and knowledge to the local firms. This leads to the economies of scale and competitive advantages to the firms which in turn enhance the productivity of the SMEs. It is therefore necessary to provide an appropriate environment to the foreign investors to bring foreign direct investment inflows in a country. Government of Pakistan may improve the infrastructure in a country to increase FDI inflows. On the other side it is need to focus on research and development programs for the small and medium scale enterprises. Access to finance can also boost the SMEs performance in Pakistan.

\section{References}

Abdullahi, I. I., \&Sulaiman, C. (2015).The determinants of small and medium-sized enterprises performance in Nigeria. Advances in Economics and Business, 3(5), 184-189.

Antwi, S., Mills, E. F. E. A., Mills, G. A., \& Zhao, X. (2013). Impact of foreign direct investment on economic growth: Empirical evidence from Ghana. International Journal of Academic Research in Accounting, Finance and Management Sciences, 3(1), 18-25. 
Baiashvili, T., \&Gattini, L. (2020). Impact of FDI on economic growth: The role of country income levels and institutional strength (No. 2020/02). EIB Working Papers.

Chughtai, M. W. (2014). Effectiveness of foreign direct investment on economic growth in Pakistan: A policy perspective approach. ActaUniversitatisDanubius. Economica, 10(4), 159-175.

Dinh, T. T. H., Vo, D. H., \& Nguyen, T. C. (2019). Foreign direct investment and economic growth in the short run and long run: Empirical evidence from developing countries. Journal of Risk and Financial Management, 12(4), 176.

Dutse, A. Y. (2008). Nigeria's economic growth: Emphasizing the role of foreign direct investment in transfer of technology. IBIMA Paper, 3(1).

Gudaro, A. M., Chhapra, I. U., \&Shaikh, S. A. (2010). Impact of foreign direct investment on economic growth: A case study of Pakistan. IBT Journal of Business Studies (JBS), 6(2).

Hussain, A. (2017). Foreign direct investment (FDI) and its impact on the productivity of domestic firms in Pakistan. Pakistan Business Review, 18(4), 792-812.

Idehen, A. V., \&Iguisi, O. V. (2020).Effect of Foreign Private Investment on the Development of Small and Medium Enterprises in Nigeria. International Journal of Research in Business and Social Science (2147-4478), 9(7), 257-266.

Jayasekara, J. P. D. R., \&Thilakarathna, A. (2013, April).Government Policy and Strategy for SME Development.In The 4th IMF-Japan High-Level Tax Conference for Asian Countries.

Khalique, M., Isa, A. H. B. M., \& Nassir Shaari, J. A. (2011).Challenges for Pakistani SMEs in a knowledge-based economy. Indus Journal of Management \& Social Sciences, 5(2).

Kunle, A. M., Olowe, S. O., \&Oluwafolakemi, F. O. (2014).Impact of foreign direct investment on Nigeria economic growth. International Journal of Academic Research in Business and Social Sciences, 4(8), 234 .

Louzi, B. M., \&Abadi, A. (2011).The impact of foreign direct investment on economic growth in Jordan. IJRRAS-International Journal of Research and Reviews in Applied Sciences, 8(2), 253258.

Manzoor, F., Wei, L., \&Siraj, M. (2021). Small and medium-sized enterprises and economic growth in Pakistan: An ARDL bounds cointegration approach. Heliyon, 7(2), eo6340.

Mwika, D., Banda, A., Chembe, C., \&Kunda, D. (2018). The Impact of Globalization on SMEs in Emerging Economies: A Case Study of Zambia. International Journal of Business and Social Science, 9(3), 59-68.

Oladimeji, M. S., Ebodaghe, A. T., \&Shobayo, P. B. (2017).Effect of globalization on small and medium enterprises (smes) performance in Nigeria. International Journal of Entrepreneurial Knowledge, 5(2), 56-65.

Oyedele, O., Kareem, T. S., \&Akanbi, F. K. (2016). Globalization and Small and Medium Enterprises Development in Nigeria: Evidence From Lagos, Nigeria. International Journal of Economics and Business Management, 2(4), 22-29.

Oyelana, A. A., \&Adu, E. O. (2015). Small and medium enterprises (SMEs) as a means of creating employment and poverty reduction in Fort Beaufort, Eastern Cape Province of South Africa. Journal of Social Sciences, 45(1), 8-15.

Rajak, P. K. (2020). Impact of Foreign Direct Investment in Micro Small Medium Enterpises (MSME) In India.MuktShabd Journal, 9(5), 1286-1295.

Ray, S. (2012). Impact of foreign direct investment on economic growth in India: A co integration analysis. Advances in Information Technology and Management, 2(1), 187-201.

Sohail, S., \&Mirza, S. S. (2020).Impact of Foreign Direct Investment on Economic Growth of Pakistan. Asian Journal of Economics, Finance and Management, 1-13.

Subair, K., \&Salihu, O. (2011).Foreign Direct Investment and Development of Small and Medium Scale Enterprises in Nigeria. African Journal of Accounting, Economics, Finance \& Banking 
Research, 7(7).

Subair, K., \&Salihu, O. (2011).Foreign Direct Investment and Development of Small and Medium Scale Enterprises in Nigeria. African Journal of Accounting, Economics, Finance \& Banking Research, 7(7).

Taiwo, M. A., Ayodeji, A. M., \& Yusuf, B. A. (2012).Impact of small and medium enterprises on economic growth and development. American journal of business and management, 1(1), 18-22.

Urata, S., \& Kawai, H. (2000).The determinants of the location of foreign direct investment by Japanese small and medium-sized enterprises. Small Business Economics, 15(2), 79-103. 